\title{
EUNICE MANIHINE SP. NOV. (POLYCHAETA: EUNICIDAE), A MEMBER OF THE FLAVUS- BIDENTATE GROUP FROM THE WESTERN EQUATORIAL INDIAN OCEAN
}

\author{
By M. R. LONGBOTTOM ${ }^{\dagger}$
}

\section{SYNOPSIS}

A new species of the genus Eunice Cuvier, I8I7, is described from $421 \mathrm{~m}$ depth in the western equatorial Indian Ocean. The characteristic features are: yellow, bidentate acicular setae, up to 4 per parapodium; up to 6 acicula per parapodium; branchiae, with few filaments, present from setiger 8 to 43 ; smooth occipital tentacles, the median reaching to setiger 24 .

\section{INTRODUCTION}

THE few surveys of polychaetes carried out in the western equatorial Indian Ocean have been restricted to intertidal and shallow-water habitats, rarely exceeding $50 \mathrm{~m}$ depth (Crossland, I904), and little is known of the fauna of the rough bottoms at greater depths. During the Royal Society Indian Ocean Deep Slope Fishing Expedition (January/February, I969), vertical bottom lines were fished from the FRV Manihine around the islands and banks in this region of the Indian Ocean (Forster et al., I970). One of these lines foul-hooked a piece of coral debris at 42I m, in which was a eunicid worm; further examination showed this to be an undescribed species of Eunice.

The genus Eunice Cuvier, I8I7, consists of a large number of valid species (approximately I40) for which the common specific characters and their variations are discussed in a recent review (Fauchald, I970). Briefly, these are the form and colour of the acicular setae (subacicular hooks), the distribution and form of the branchiae, and the length and form of the occipital tentacles. Combinations of these and, frequently, other characters serve to distinguish the species, only rarely is one of these major characters alone sufficient. Major divisions, based on the form and colour of the acicular setae, were suggested by Hartman (I944), resulting in four groups of those species for which the relevant details were known. This system has been expanded to include a greater number of valid species, and, based on the distribution of the branchiae, five subdivisions have been proposed for each of seven groups (Fauchald, I970).

\section{DESCRIPTION}

The single specimen of Eunice manihine sp. nov. consists of I27 setigers and is approximately $75 \mathrm{~mm}$ long $(9 \mathrm{~mm}$ from the tip of the palps to the posterior edge of the tenth setiger on the dorsal side, following Fauchald, I970) and $5 \mathrm{~mm}$ wide. The 
specimen is cylindrical in the anterior region, and becomes flattened towards the posterior.

The anterior margin of the prostomium is distinctly notched between the palps (Fig. I). The length of the prostomium is slightly greater than half the breadth. The prostomium bears a pair of eyes posterior to the gap between the bases of the
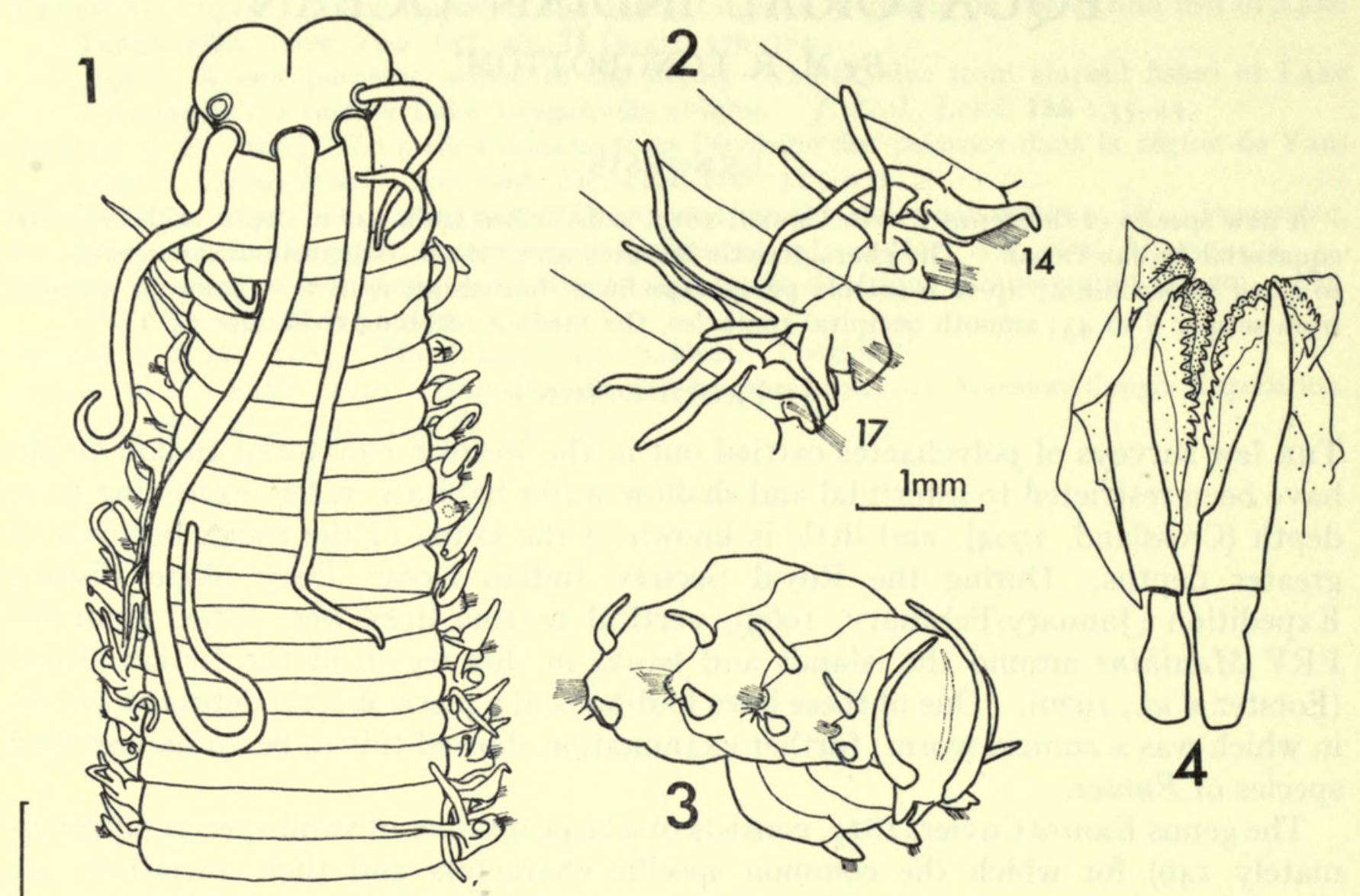

$5 \mathrm{~mm}$
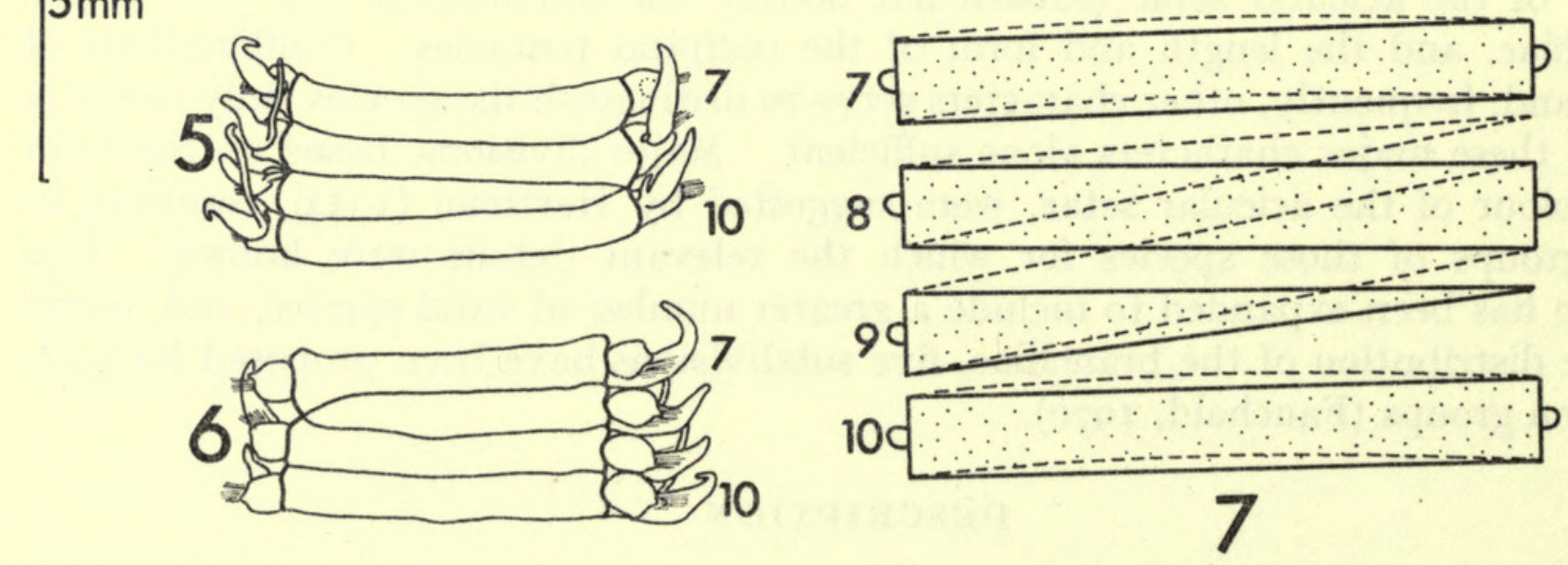

Figs I-7. Eunice manihine. I. Anterior end, dorsal view (left outer occipital tentacle missing). 2. Setigers $\mathrm{I}_{4}-\mathrm{I} 7$ right side, dorsal view. 3. Posterior end, left lateral and slightly ventral view. 4. Maxillary plates, dorsal view. 5. Setigers 7-ro, dorsal view. 6. Setigers 7-10, ventral view. 7. Setigers 7-10, diagrammatic representation, dorsal side firm lines. 
inner and outer occipital tentacles (Fig. I). Five smooth and very long, slender tentacles are present; the unpaired median tentacle reaching back to setiger 24, the inner lateral tentacles reaching setiger I2 and the outer laterals setiger 3. The first peristomial segment is two thirds the length of the prostomium; the second peristomial segment is half the length of the first and the same length as the first setiger. The peristomial cirri are smooth and reach just beyond the posterior border of the prostomium.

The maxillae are well developed (Fig. 4); maxilla I is falcate; maxilla II has I2 teeth left and II teeth right; maxilla III has I2 teeth left; left maxilla IV has II teeth and the combined right maxillae III + IV have I3 teeth; each maxilla V has I tooth.

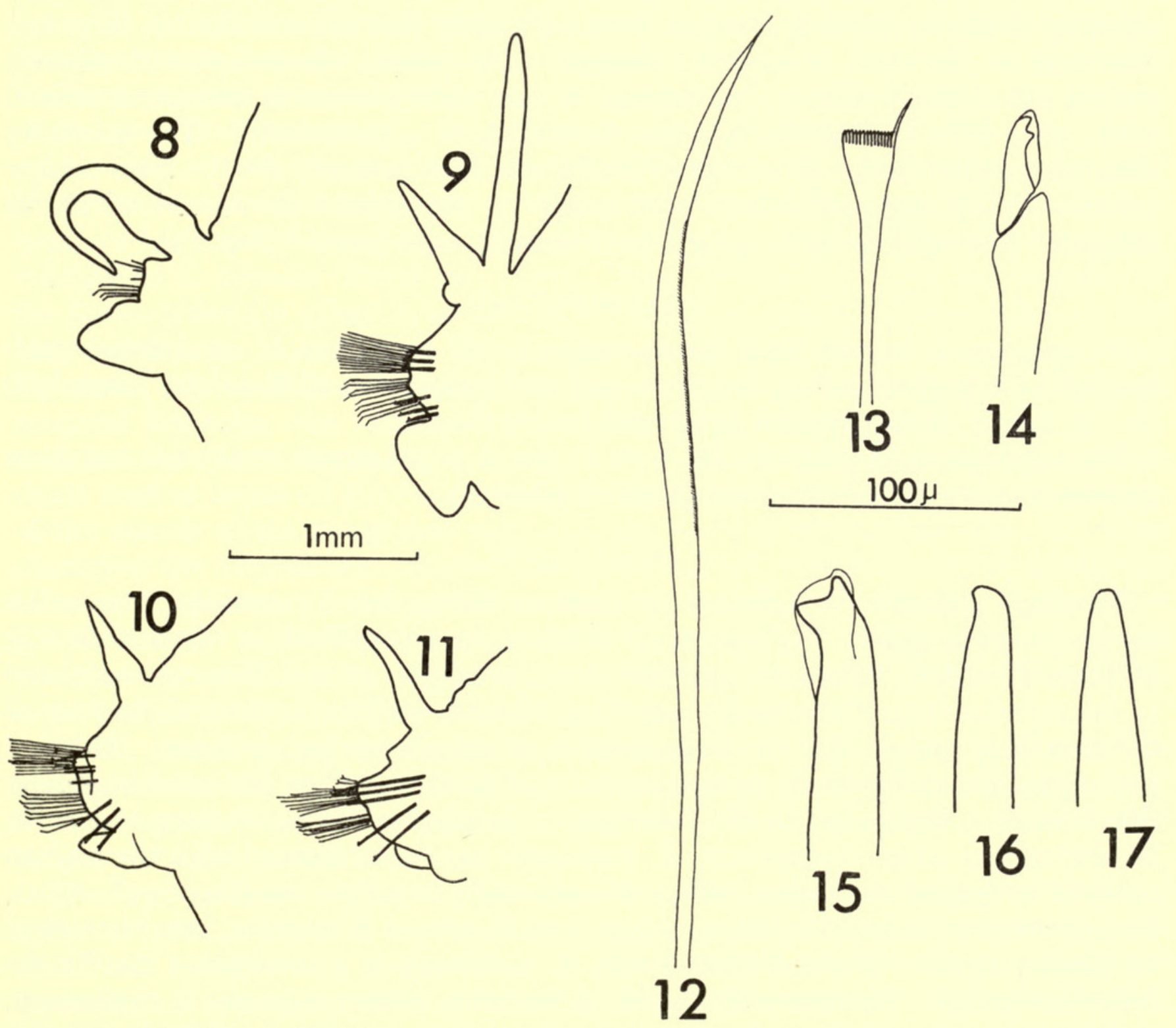

Figs 8-I7. Eunice manihine. 8-II. Parapodia from right side, anterior view. 8. Setiger 4. 9. Setiger 34. Io. Setiger 6o. II. Setiger 90. I2. Capillary seta from setiger 90. I3. Comb seta from setiger 90. I4. Falcigerous seta from setiger 34 . I5. Acicular seta (subacicular hook) from setiger 34. I6. Aciculum from setiger 34 . I7. Aciculum from setiger 6o. 
Branchiae are present only in the anterior third of the specimen: from setiger 8 to setiger 43. The branchiae consist of a single filament anteriorly (Fig. I) with a maximum of 3 filaments between setigers I7 and 22 (Fig. 2), decreasing posteriorly to a single filament. The filaments are thinner than the dorsal cirri in the branchial region (Fig. 2). The dorsal cirri are smooth, anteriorly with a stout base and elongated tip (Fig. 8), posteriorly digitiform (Figs $3 \&$ II). The ventral cirri are subulate (Figs 3, 6, 8-II). Two pairs of anal cirri are present (Fig. 3), the dorsal pair long and the ventral pair very short.

In the majority of the parapodia there are, superiorly, between Io-I8 long, slightly limbate, capillary setae with weak striations (Fig. I2), and, towards the posterior, 5-9 comb setae with I4-I6 teeth, usually with the outer tooth on one side appreciably longer (Fig. I3). Inferiorly, there are 7-9 falcigerous setae, the blades of which are strongly bidentate, with a rounded hood projecting just beyond the tip (Fig. I4). The head of the shaft is slightly enlarged. The acicula are yellow with slightly curved tips (Figs I6 \& I7). An average of 3 or 4 are present in each parapodium, with up to 6 in the middle setigers, decreasing to 2 posteriorly. The inferiorly situated acicular setae (subacicular hooks) are first present, singly, from setiger $27 / 28$, with 3-4 per parapodium from setiger $3 \mathrm{I}$ throughout the remainder of the setigers. The acicular setae are yellow, bidentate, and hooded (Fig. I5).

\section{DISTRIBUTION}

E. manihine is known from one specimen found in a piece of coral debris foulhooked on a bottom fishing line from $42 \mathrm{I} \mathrm{m}$ depth, south of Menai Is, Cosmoledo $\left(10^{\circ} \mathrm{S}, 47^{\circ} \mathrm{E}\right)$, in the western equatorial Indian Ocean.

The type specimen (Ref. no. ZB I97I·I) which is preserved in alcohol has been deposited in the British Museum (Natural History).

\section{DISCUSSION}

No single character is sufficient by itself to distinguish $E$. manihine from other members of the genus; the separation is based on a combination of the following characters: yellow, bidentate, acicular setae; branchiae of few filaments restricted to the anterior third of the body; very long, smooth, occipital tentacles; the form of the maxillary plates; and the large number of acicula per parapodium. The first two characters are common to many species of Eunice and are discussed in greater detail beiow. References in the literature to occipital tentacles reaching to near or beyond setiger 20 are uncommon: E. antillensis has been recorded with the median tentacle to setiger 20 (Ehlers, I887), E. auriculata to setiger I8 (Treadwell, I90I), E. palauensis to setiger I8 (Okuda, I937), and E. tibiana (Pourtalès, I863) to setiger 22 (Izuka, I9I2). Of these species only E. antillensis is a member of the flavusbidentate group. However, the degree of variation within a species is not known, and to some extent is dependent upon the state of preservation. This also applies to the form of the tentacles, whether they are wrinkled or clearly articulated. The presence of as many as 6 acicula per parapodium is very unusual, contrasting with the more normal number of $\mathrm{I}-3$ for species of Eunice. The number of teeth on the maxillary plate is also greater than is usually found in the genus. 
Adoption of the system of subdivision proposed by Hartman (I944) and Fauchald (I970) enables comparisons to be made more easily within this large genus. $E$. manihine, in possessing yellow, bidentate acicular setae, clearly belongs to the flavus-bidentate (A) group of Hartman (I944), and from the distribution of the branchiae (commencing before setiger Io and not present after setiger I0o), to subdivision I of Fauchald (I970). As the numbers of setigers may vary in worms of different sizes, it is suggested that the definition of this subdivision should be expanded to place the emphasis on the branchiae being present in the anterior third of the body rather than within a definite number of setigers irrespective of the size of the worm.

Fourteen species are listed by Fauchald (I970) within this group AI to which should be added E. semisegregata Fauchald, I970, and from which should be removed E. benedicti (Verrill, I885) - a synonym of E. pennata (Müller, I776) (see Pettibone, I963) - and E. norvegica (Linnaeus, I767). The latter, in having black bidentate acicular setae, and branchiae present from setiger 3 to within a few setigers of the anus (Pettibone, I963), should be placed in the fuscus-bidentate (B) group, subdivision 2. All the previously described species in the AI grouping have the branchiae commencing on setiger 3. Fauchald (I970) has suggested that this is a constant feature within a species, though small variations have been recorded, as for example in E. pennata (Pettibone, I963). Thus, E. manihine is the sole member of the flavus-bidentate group in which the branchiae commence before setiger Io, but after setiger 6. Apart from E. manihine, only two species-E. megabranchia Fauchald, I970 and E. validobranchiata Monro, I937- in the AI group have smooth occipital tentacles, the remainder have articulated or moniliform tentacles. $E$. megabranchia (from $894 \mathrm{~m}$ depth in the Gulf of California) and E. validobranchiata (from I046 m depth off the South Arabian coast) differ only in the length and shape of the guards of the falcigerous setae and the form of the ventral cirri; the other characters are very similar and for comparison with $E$. manihine may be considered identical. Specimens of these two species of a similar size to the E. manihine specimen differ in having branchiae with large numbers of filaments (up to 45) commencing on setiger 3, appreciably shorter occipital tentacles, fewer acicular setae per parapodium and fewer teeth on the maxillary plates.

Of the eunicid polychaetes reported from East Africa (Crossland, I904), only one species of the flavus-bidentate group was reported-E. tubifex Crossland, I904. This belongs to Fauchald's subdivision 4, in which branchiae are present from after setiger ro to the posterior.

The type specimen of $E$. manihine shows an abnormality in the segmentation of setigers 8 and 9 (Figs $5 \& 6$ ), resulting in a short spiral (Fig. 7) similar to the form Buchanan (I893) found in specimens of Lumbriconereis impatiens (=Lumbrinereis tetraura). It was not possible to examine the internal anatomy of the single specimen available.

\section{ACKNOWLEDGEMENTS}

I am most grateful to Dr. O. Hartman and Professor J. H. Day for confirming the separate identity of the species, and to Dr. J. D. George and Mr. P. M. David for 
reading the manuscript. Study leave was granted by the University of Newcastle upon Tyne for the period of the expedition, which was financed by the Royal Society.

\section{REFERENCES}

Buchanan, F. 1893. Peculiarities in the segmentation of certain polychaetes. Q. $J l$ microsc. Sci. 34 : 529-544.

Crossland, C. 1904. The marine fauna of Zanzibar and British East Africa, from collections made by Cyril Crossland in the years I90I and 1902.-The Polychaeta. Part III. With which is incorporated the account of Stanley Gardiner's collection made in the Maldive Archipelago in the year 1899. Proc. zool. Soc. Lond. 1 : 287-330.

EHLERS, E. 1887. Report on the annelids of the dredging expedition of the U.S. Coast Survey steamer Blake. Mem. Mus. comp. Zool. Havv. 15 : I-335.

Fauchald, K. I970. Polychaetous annelids of the families Eunicidae, Lumbrineridae, Iphitimidae, Arabellidae, Lysaretidae and Dorvilleidae from Western Mexico. Allan Hancock Monographs in Marine Biology 5 : I-335.

Forster, G. R., Badcock, J. R., Longbottom, M. R., Merrett, N. R. \& Thomson, K. S. 1970. Results of the Royal Society Indian Ocean Deep Slope Fishing Expedition, I969 Proc. R. Soc. B. $175: 367-404$.

Hartman, O. 1944. Polychaetous annelids. Part 5. Eunicea. Allan Hancock Pacific Exped. 10 : $1-238$.

Izuka, A. I912. The errantiate Polychaeta of Japan. J. Coll. Sci. imp. Univ. Tokyo 30 (2) : $\mathrm{I}-262$.

OKUDA, S. 1937. Polychaetous annelids from the Palau Islands and adjacent waters, the South Sea Islands. Bull. biogeogr. Soc. Japan 7 : 257-316.

Pettibone, M. H. I963. Marine polychaete worms of the New England region. I. Families Aphroditidae through Trochochaetidae. Bull. U.S. natn. Mus. 227 : 1-356.

Treadwell, A. L. igor. The polychaetous annelids of Porto Rico. Bull. U.S. Fish Commn 20 : I8I-2 I0.

Dr. M. R. Longbottom

National Institute of OCEANOGRaphy

WORMLEY

Godalming, Surrey 


\section{$2 \mathrm{BHL}$ Biodiversity Heritage Library}

Longbottom, M R. 1972. "Eunice manihine sp. nov. (Polychaeta: Eunicidae), a member of the flavus-bidentate group from the western equatorial Indian Ocean." Bulletin of the British Museum (Natural History) Zoology 21, 339-344. https://doi.org/10.5962/bhl.part.10156.

View This Item Online: https://www.biodiversitylibrary.org/item/19475

DOI: https://doi.org/10.5962/bhl.part.10156

Permalink: https://www.biodiversitylibrary.org/partpdf/10156

\section{Holding Institution}

Natural History Museum Library, London

\section{Sponsored by}

Natural History Museum Library, London

\section{Copyright \& Reuse}

Copyright Status: In copyright. Digitized with the permission of the rights holder.

Rights Holder: The Trustees of the Natural History Museum, London

License: http://creativecommons.org/licenses/by-nc-sa/4.0/

Rights: http://biodiversitylibrary.org/permissions

This document was created from content at the Biodiversity Heritage Library, the world's largest open access digital library for biodiversity literature and archives. Visit BHL at https://www.biodiversitylibrary.org. 